\title{
Function Words of Andio Language Viewed from Syntactical Aspect
}

\author{
Baso Andi-Pallawa \\ Tadulako University, Indonesia - 2006 \\ Email: andipallawab@rocketmail.com
}

\section{Doi:10.5901/ajis.2013.v2n2p175}

\section{Abstract}

This research describes the function words of Andio Language in terms of the function word types. For examples: (1) noun determiners, (2) qualifiers, (3) prepositions, (4) coordinators, (5) interrogators, (6) subordinating conjunction, (7) sentence linkers, (8) modal auxiliaries, (9) interjection, (10) aspect words, and (11) particles and (12) relative pronouns. The significance of this study is expected to produce the descriptive data of those types of function words, to furnish information for those who are interested in carrying out another study concerning with Andio language, to help the teaching of local content course, such as function words themselves of Andio language and to contribute to the Department of National Education, particularly in Central Sulawesi for the consideration as development of the local content course curriculum. The design of this study is descriptive qualitative. It is based on the process of investigation involving description and interpretation that can be assigned without manipulating any variables. The subjects of this study are the native speakers of Andio language at Lamala district, Luwuk Banggai regency in Central Celebes (Sulawesi).

Keywords: function words, syntactic aspects, andio language,

\section{Introduction}

Language is one of the most important and normal forms of human behavior. It always has a place in the academic world where its position has converted seriously: at one time the investigation of language is almost completely limited to specific languages, particularly those of their speakers are decreasing that make those languages undergo extinction.

As focused on the importance of language, each of the social sciences has broaden it has met language problems within its area. Psychology, sociology, and anthropology have each studied language both as a type of human activity and as a system interrelating with personality, society, or culture. Language broken in even upon technological problems, and engineers have discovered driven to basic study on human speech. Consequently, many of language experts have created techniques for the investigation of language from a number of different points of view. Each of these techniques adds to all the others in providing theoretical knowledge and the practical problems of the day. For example, one approach has obtained a little bit attention until very recently: Descriptive linguistic which studies languages in terms of their internal structures. It differs from the other approaches in that it focuses on different aspects of human speech. The conventional broad subject matter and its special competence to overcome particular types of problems carry it into important connections with many other disciplines.

In line with what has been stated above, it can be said that language is the expression of all these things developed through communication among members of the community and the culture it represents. Language, like culture, is community specific and is complicatedly interconnect with the culture it represents. Language helps members of the community to establish, defend and maintain their identity as individuals and as a group, bringing among them a sense of solidarity. Language acts as medium of instruction on the one hand and as a tool of developing relationship with its areas on the other. It helps to develop thoughts that need to be presented with integrity and solidity.

Besides, language has a lot of interrelationships with a variety of aspects of human life that it can be studied from different points of view in which linguistics plays the important role in understanding language. Gordon (2005) states that linguistics is the science which attempts to understand language from the point of view of its internal structure in which three major components of language, as far as language extend out within the series of linguistics, are the structure of expression, the structure of content, and vocabulary. The latter covers all the specific relations between expression and content - in the common terminology, words and their meanings. 
Pertaining to the above statements, vocabulary comes and goes. It is the least constant and even the least characteristic of the three components of language. That part of the vocabulary which amends or looses most freely is sometimes referred to as "slang." But even archaic words are always being created and persistently passing out of active use, to be protected only in literature which is dated by their very presence. While particular types of words are more short-lived than others are, none is absolutely never-ending, and even the most familiar and commonly used words, which might be expected to be most stable. Moreover, in the life history of an individual speaker the birth and death of words is very much more normal than in the language community as a whole. Consequently, any language is extinction whenever its speakers increase of being death, let alone if the language is not used by its indigenous (native) speakers in their daily life or in their community.

Regarding to what has been stated above, Gordon (2005) continues stating that there are some different tactics to the categorization of language endangerment. According to him, the total number of languages in the world is 6,912 . Of the languages listed, 516 are classified as almost extinct, as "only a few elderly speakers are still a life." A language might be regarded as endangered when it is exerted only by socially isolated old folks, a socially integrated inhabitants away from a child bringing ages, and when it survives only orally, without literacy. Rau, et al., (2007) define three groups of endangerment: (1) vanishing languages: no longer learned by children, (2) endangered languages: still learned by children but not expected to be learned by children within ten years, and (3) protected languages: supported by the state and having a large number of speakers. It is approximated that $90 \%$ of the existing oral languages will either be on our deathbed or will have vanished by the end of the century. Thus, there is a very limited window of opportunity to record and renew (regenerate) those languages.

Based on the above information, research done by Summer Institute of Linguistics (1985) suggests that among the 735 vernaculars in Indonesia recorded, 637 are endangered with less than 100,000 native speakers. Along with the strong campaign of the government to speak "Good Indonesian" and the fact that English is promoted starting at primary education, the portrait of multilingualism in Indonesia is unfortunately severely deteriorated (get worse, worsen, decline, depreciate, go down, weaken).

Based on these facts, it is depressing to say that multilingualism in Indonesia is in a real state of catastrophe (disaster, calamity, upheaval, devastation misfortune, tragedy). While local languages or vernaculars as diverse as Batak, Malay, Sundanese and Javanese, which provide a rich array of linguistic research that might be of interest to many scholars worldwide, the conservation of these vernaculars is far from satisfactory.

Andio language exists at Lamala district at two villages - Taugi and Tangeban villages. These villages are situated about 50 kilometers to the sea eastern part of the regency capital of Luwuk Banggai in Central Sulawesi. Around 1.150 native speakers of this language speak it (Data of population census of two villages, 2004). Therefore, this language must be inventoried to avoid its extinction.

Based on this background, the researcher formulated the research question: "What types of function words does Andio language have?" In line with this research problem, the main purpose of this study is to describe and inventory the types of functions words Andio language has.

Andio language is very importantly investigated, and in concurrently inventoried to preserve local cultural elements; it also provides contribution toward the local linguistic development in particular and the national linguistic development in general. The statements above induced the researcher to carry out a study about the function words of Andio language as one of vernaculars existing in Central Celebes (Sulawesi Tengah).

\section{Research Methods}

The design of this study is a descriptive qualitative. It is based on the process of investigation involving descriptions and interpretations that can be assigned without manipulating variables. In other words, this study is qualitative in nature, trying to explain and describe data, which are written in the form of field-notes.

This research reveals findings not by tools of statistical procedures or other devices of quantification. Based on this feature, this study is named "qualitative research because its main method of data collection is closely related to observation, interviews, and recording.

This research was conducted at Lamala district of Luwuk Banggai regency, about fifty kilometers to the sea eastern part of the capital of Luwuk Banggai regency. It was carried out at two villages of this district: Taugi village and Tangeban village. Its subjects were the native speakers and indigenous villagers of Lamala district. Although the indigenous villagers of this district were not so large, it was still difficult for the researcher to consult all population. As a 
result, nine informants selected were the subjects of this research. These subjects were chosen on the basis of what Bogdan and Biklen (1983) state that in qualitative research such as a descriptive study, the researcher may have one single subject or more than one subject. The subjects can be representative of all target indigenous villagers who speak that language. Therefore, nine subjects were indigenous speakers having their own culture selected as the subjects of this study. They used and spoke that Andio language in their daily life and society, and knew and mastered the rules of that language well. In short, all of them were the indigenous speakers of the Andio language at Tangeban and Taugi villages.

\section{Findings and Discussion}

The descriptions of the findings are directed to answer the research question: "What types of function words does Andio language have?" In line with the research problem, the following are the answers of the query above. below.

Based on the findings, it has been found that Andio language has several function words as presented respectively

\subsection{Function Words Viewed from Syntactical Feature}

When a function word of Andio language is observed on the basis of syntactical feature, it cannot form a sentence consisting only one word as a complete utterance. This means that the function word has meaning if it is connected to another word in a phrase or a sentence, for instance, the function words / tiba / 'and,' / i / 'in, at, to,' / utadumai / 'from,' will have meanings if they are connected with another word. Consider the following examples: / so:pan tiba lawan / 'door and window,' / inabu / 'in the garden,' / utadumai kauno / 'from the river.'

\subsection{The Types of Function Words of Andio Lamguage}

Almost all function words of Andio language cannot undergo the process of form changing. The following are the transcript excerpts of function word:

Noun Determiners - are words that always appear before nouns. This group includes the articles: / sa?angu / 'a, the'; other words that indicate that a noun follows: / aiya / 'this,' / aido / 'that,' and words that appear before a noun or substitute for a noun: / biai / 'many,' / topopia / 'several,' / bibi?no? / 'all' /kiki? / 'each,' / te?ineng / 'few.' The following are the examples.
1. / sa?angu / 'a, the'
2. / aiya / 'this'
3. / aido / 'that'
4. I topopia / 'several'
5. / bibi?no?/ 'all'
6. / ki:ki? / 'each'
7. / te?ineng / 'few'
8. / / biai / 'many'

\author{
/ sa?angu kauno / 'a river' \\ / aiya karambau / ' this buffalo' \\ / aido manuk / 'that hen, \\ / topopia mian / 'several persons' \\ / bibi?no? sawe? / 'all people' \\ / ki:ki? bobine / 'each girl' \\ / te?ineng du? ong / 'few fish' \\ / biai bonua / 'many houses'
}

Qualifiers - are words that qualify adjectives and adverbs, limit or intensify their meaning, such as: / tararu / 'very,' I totutotu? / 'obsolutely,'/ gana? / 'rather,' / ka? / 'rather' is used for astonish, / sukup / 'enough'- is used to modify an adjective, / sampa? / 'enough' - is used to modify a noun.
1. I tararu / 'very'
2. I totutotu?u / 'obsolutely'
3. I gana? / 'rather'

/ ka? / 'rather'- is used to state astonishing with rising intonation.

\author{
/ tararu makeker / 'very diligent' \\ / totutotu?u bu?o / 'obsolutely new' \\ / gana? bonian! / 'rather smell!'/ \\ / gana? mindalan / 'rather expensive' \\ / ka? mamuda! / 'rather cheap!' \\ / ka? mamuda / 'rather cheap' \\ / ka? mindalan / 'rather expensive' \\ / ka? bonian / 'rather smell'
}


4. / sukup / 'enough' - is used to modify an adjective

5. / sampa? / 'enough' - is used to modify a noun.

6. / lai? / 'still'
/ sukup la:ndue? / 'pretty enough'

/ sukup ma?asing / 'sweet enough'

/ sukup miankupangon /' rich enough'

/ sampa? uwe / 'enough water'

/ sampa? doi? / 'enough money'

/ lai? Royot / still sleep'

\subsection{Subordinate Conjunctions}

A subordinate conjunction introduces a clause that depends of a main or independent clause. The subordinate conjunction is grammatically part of the clause it introduces; it is never separated from its clause by a comma. Further, All the introductory words in the three subordinate clauses, even pronouns or adverbs, may be classified as subordinate conjunction (Frank, 1972).

In line with the statement above, it has been found that Andio language has several subordinate conjunctions: I lapas/ 'after,' / maumule? / 'even though,' / sampe / 'if, when,' / da / 'in order that,' / gau / 'because,'

The following are examples stated below:

1. / lapas / 'after'

2. / teing:gu / 'before'

3. I maumule? / 'even though'

4. I sampe / 'if, when'

5. / da / 'in order'

6. I gau / 'because'
I kita toali mongka:n lapas molabu/'We may eat after bathing'

/ ara?tu ba:la toali ma:pa teing:gu mongkabai /

'They may not go before eating.'

/ i inde? mombusoi alumbu? maumule? Inango mopane /

'Mother washes a piece of blanket even though she is sick'

I komiu mokoala monginkat batu ba?an aiya sampe komiu nutulungi u nian sanga?at/ 'You can left this big stone if you are helped by other people.'

I inango te:nggu moturu da inango tendesi/

'S/he must sleep in order that s/he is healthy.'

/ tai?to mopane gau ka? inango mongka:n kakan mose: /

'Your grandfather is sick because he eats stale rice.'

\subsection{Relative Pronounce}

Relative pronouns refer to noun antecedents which immediately precede them. They introduce adjective clauses in which they serve as subjects or objects (Frank, 1972). Based on this explanation, it has been found that Andio language has only one relative pronoun, that is / mian / 'which, who.' Here the examples are below.

1. I karambau, mean ningso:p i inabungku lapasmo nirakop ri?itu/

'The buffalo, which enters my garden, has been recently caught.'

2. I pateleng, mian tarabut, nomate / 'The fisherman, who sails, dies.'

3. I perapa, mian notoka i bonuangku, momboboki aku? / 'The robber who came to my house, beat me.'

\subsection{Coordinate Conjunctions}

The coordinate conjunctions join structural units that are equal grammatically. The conjunction comes before the last unit and is grammatically independent of this unit (Frank, 1972). Referring to these function words, it has been found that Andio language has coordinate conjunctions as presented in the following examples below:
1. I t tiba/ 'and'
/ $\mathrm{i}$ inde? momeso pae tiba i tume monta: kau /
'Mother pounds rice and father cuts a tree'
2. / kabai / 'or'
I komiu da: bakakae? i bonua kabai bakakae? i inabu /
3. Iko:ai?itu / 'but'
'You may work at home or work in the garden'
/ ara?itu lapasmo nongka:n ko:ai?itu aku? ba:lape:no /
'They have already eaten but I have not.'
/ tuma lapasmo nontu:i? lombong ko:ai?itu ina ba:lape:no /
'Father has already kept the pool but mother has not,




\subsection{Transitional Signals / Sentence Linkers}

The two terms written above are synonyms in which the formal devices are used to combine sentences into continuous text. They provide logical relationships that hold between sentences or stretches of text, marked by the use of logical connectors (Mackay et al., 1979). The discourse markers are functions words used to support and enlarge a main idea in a paragraph. With respect to this statement, Andio language has been found having sentence linkers, such as:
1. I gau?ni / 'for example, so',
4. I kopupusano / 'finally'
2. / singkosingko/ 'for example'
5. I tumbetumbeno / 'firstly'
3. I lapas aitu / 'furthermore'

The following are the examples of those sentence linkers used in a short paragraph:

I Bitu?on tibungkukan aku? nomea samian bobine kupangon kaekae u rapa. Tumbetumbeno (1), aku? nontoa? samian ma:ne nombaba tetep ka? nongurut tetepno aido ani bobine kupangon aido. Lapas aitu (2) porapa aido nongala bibi? no mosoni u bobine aido. Lapas aitu (3) i porapa nasasinggolat nomuli:si ningkelan aido mian rapa:nno. Kopupusano (4) inango ma:pa mombini i inabu u loka. I 'Last month, I witnessed a rich woman was being robbed. At first (1), I saw a man holding a knife and stuffed it to the rich woman. After that (2), the robber took all woman's gold. Further (3), the robber left the location quickly together his robbed goods. Finally (4), he hid himself in the bananas garden.'

\subsection{Prepositions}

Prepositions as well as conjunctions differ from other parts of speech in that (1) each is composed of a small class of words that have no formal characteristic endings; (2) each indicates syntactic structures that function as one of the other parts of speech. They are classified as structure words rather than as parts of speech (Frank, 1972). In line with this statement, Andio language has been found having several prepositions:
1. / bobou / 'about'
2. / kinana?uno / 'during, since'
3. / ola? / 'between'
4. / ara?arani / 'around'
5. / ka:uta / 'above'- for high place
6. / ka:urong / 'down' - to the sea'
7. / ka:udo / 'to' - north, south, eft, etc.
8. / / / 'to, at, the/a'
9. / u / 'in, at, by'
10./ ani / 'attention to'
11. / utadumai / 'from'
12. / sarata: / 'since'
13. / singkasingka / 'together'

The following are their examples in some simple sentences:
14. / sulanomo / 'than'
15. / kaba?/ 'until, till'
16. / tiba / 'with, and'
17. / babo: / 'on'
18. / patu / 'below'
19. / soripi? / 'beside'
20. /sambira / 'out, across, beside'
21. / rarom / 'nside'
22. / susu / 'corner'
23. / apar / 'beneath'
24. / gau = ka? / 'because'
25. / bo?a: / 'for'
26. / singko / 'same'
27. I tikutikum / 'around'

1. / i / 'in, at, to'

2. / kauta = ka:uta / 'to' is used to a high place.

I malo?ku molobu i kauno / 'My father takes a bath in the river' / tuma ma:pa i bonebakal / 'Father goes to Bonebakal'

/ topesanno ma:pa kauta baboon / 'His/her cousin goes up to a mountain.' / perapa aido mimpololo? ka:uta atop u bonua / 'The robber runs to the roof of the house'

3. / kaurong = ka:urong / 'to' is used to a low place.

I malo?(tuma) mombuntul pitno kaurong ku:ra?/

'Father pushes the bicycle to a ditch.' / ara?itu mobose duangan aido ka:urong tasi /

'They row the boat to the sea.'

4. / bo?ai / 'for' 
5./ tiba = mian / 'with'

6. / mian / 'with' - as an adverb qualitative.

7./ singkona ...tiba / 'similar to'

8. / bobou / 'about' /

9. / sarata / 'during'

10. / kaba? / 'until'
'My uncle brings potatoes for my father.'

I tina mosea isi: tiba piso?/ 'Mother sliced meat with a knife.'

/ aku? mongka:n tiba utus eti?ku / 'I eat with my young brother.'

I ara?itu lumempang mian madidik / 'They walk quickly'

/ posambaingku mobose duanganno mian poponiak /

'My friend rows his boat slowly.'

/ pasanga?ku singkona kobu?ono tiba pasanga? miu /

'My shirt is similar to yours.'

/ aku? montulis bobou pateleng u bonebakal /

'I write about the fishermen of Bonebakal.'

/ malo?ku nokoro bonua sarata tumangku niingkat singko tonggol /

'My father built a house during my father was assigned as a village chief.'

/ ba:bo?ku bo: mombuani du?ong kaba? ma?uloulop /

'My uncle will net fish until morning.'

\subsection{Interrogators}

The interrogators are function words used to ask something that expects a reply supplying an item of information. They refer to interrogative adverbs and pronounces (Quirk and Greenbaum, 1973; Frank, 1972). Based on this statement, Andio language has been found having interrogative adverbs and pronounces. The Andio interrogators do not involve any auxiliary verbs of to be or to do because it does not have them as the English does. The following are the examples of interrogators of Andio language.
1. / ka?ipian / 'when' for past event
7. / da?asi? / 'what'
2. / ipiando / 'when' for future.
8. / nongapa: / 'why'
3. / i ari:no / 'in where'
9. / so?isoma / 'how'
4. / ari: / 'where'
10. / meanari: / 'which'
$5 . /$ ari / 'from where'
11. / inde: / 'who'
6. / apa: / 'what'
12. / aninde: / 'whose'

The following are the examples of the above interrogators of Andio language:

1. / ka?ipian / 'when' is used for a past event. / ka?ipian ara?itu notoka utadumai Batui?

/ 'When did they arrive from Batui?'

/ ka?ipian oko nongoli pit aiy ? I

'When did you buy this bicycle?'

2. / ipiando / 'when' is used for a future event. / ipiando kita bo: mongkeke bubung ? / 'When shall we dig a well?'

/ ipiando oko bo: mongoli pit aiya ? /

'When will you buy this bicycle?

3. / nongapa / 'why'

/ nongapa inde? miu tumangis ? I

'Why does your mother cry?'

/ nongapa malo?to maso? ? / 'Why is your father angry?'

4. / ari: / 'where'

/ ari: pasanga?ku i:ya ? / 'Where is my shirt here?'

/ ari: bonua miu ? / 'Where is your house?'

5. / mianari: / 'which'

/ mianari: oko mongkira? ? / Or / oko mongkra?

mianari:? / 'Which do you like?'

/ mianari: komiu bo: mongka:n ? / Or / komiu bo:

mongka:n mianari: ? / 'Which shall / will you eat?'

6./ so?isoma / 'how'

/ so?isoma komiu morakop jonga ? I

'How do you catch the deer?'

/ so?isoma galagat u ara?itu ? / 'How is their temper?'

7./ popia / 'how many' 'how much'

/ popia mian gaga?imiu ? / How many people you call?'

/ popia oli u pit aiya ?/How much does this bicycle cost?' 
8. / inde: / 'who'

9. / tiba inde: / 'with whom'

10. / tiba apa: / 'with what or by what'

11. / apa: / 'what' - past event.
/ inde: morakop jonnga ? / 'Who catches the deer?'

/ inde: momapatei u ulo? ? / 'Who kill the snake?'

/ tiba inde: oko ma:pa kaurong tasi ? I

'With whom do you go to the sea?'

/ tiba inde: ara?itu notoka i bonuam ? / - past event. 'With whom did they come to your house?'

/ tiba apa: malo? momo: i asu? I

'What does father beat the dog with?'

/ tiba apa: ara?itu nongkeke bubung ? I

'With/By what did they dig the well?'

/ apa: i babo: gana:f ? / 'What is on the table?'

/ apa: bo: nibaluk u ara?itu ? / 'What will be sold by them?'

/ apa: bo: tina mongka:n ? / 'What will mother eat?'

\subsection{Modal Auxiliaries}

Modal auxiliaries add to the verb a special semantic component such as ability, obligation, and possibility. In line to this statement, Andio language has been found having modal auxiliaries, such as:
1. / bo: / 'will, shall'
3. / toali = da: / 'may'
2. / tioda: / 'must'
4. / mokoala / 'can'

The following are the examples of the above modal auxiliaries of Andio language:
1. / bo: / 'will, shall'
2. / tioda: / 'must'

I ara?itu bo: ma:pa kauron tasi no?ila / 'They will go to the sea tomorrow'

I i naung bo: toka udodumai ampana / 'Aunt will come from Ampana.'

/ tinanto tioda: mongkalesang malo?to /

'Your/our mother must take care your/our father.'

/ kita tioda: montulungi i inde? mongundan i polu? I

'We must help our mother cook in the kitchen.'

/ oko tioda: mongka:n sa?ia / 'You must eat now.'

3. / toali / 'may'

/ oko toali ma:pa moturu sa?ia / 'You may go to sleep now.'

I komiu toali notoka i bonuangku /

'You (polite pronounce) come to my house.

4. / da: / 'may'

5. / mokoala / 'can'

I ara?itu da: balimang i inabunku? / 'They may work in my garden.'

I ba:bo?ku mokoala monginkat batu ba?an aiyal

'My uncle can lift this big stone.'

/ tai? mami mokoala mongator komiu kaurong tasi /

'Our grandfather can accompany you to the sea.'

\subsection{Aspects}

Aspect referring to certain verbs, often with accompanying adverbial expressions, may indicate whether an event is to be regarded as a single point on a time continuum, a repetition of points, or a single duration with a beginning, a middle and an end. It is the aspect of duration that a verb most readily expresses through the progressive forms of the tenses (Frank, 1972). Based on this explanation, Andio language has been found having function words that are concerned with aspect. The following are the examples of aspect stated below:

1. Future aspect: / bo: / - / tina bo: mongka:n loka? / 'Mother will eat a banana'

2. Progressive aspect: / kaekae / - / langkai?ku kaekae monsinanga du?ong / 'My husband is frying fish.

3. Perfective aspect: / lapasmo + noN- + verb / 'aku? Lapasmo nongoli pasanga?/ 'I have bought clothes.'

I kita lapasmo nokekei bolo? / 'We have dug the hole.'

\subsection{Interjections}

Interjections are function words used to express human's feelings, such as sad, hurtful, astonishing, disgusted, angry, and admiring. In general, the interjection refers to an attitude of (1) negative, (2) positive), (3) astonish, and (4) expecting 
an attention that depends on the sentence purpose that follows it. Referring to this explanation, Andio language has been found having function words of interjections:

1. Disgusted, angry and regretting interjections

/ se?! = pue!, insamo tongko oko ma?ane! / 'Phew!, not only you, a man!'

/ ebe:!, so?isamo nabisaram! / 'Ouh!, how come you say like that!

/ kampanang!, mari:ngi? To:tuyu? Oko aiya! / 'My God!, how dirty you are!'

/ o:! , sa?itu gau?no! / 'Oh!, that is his/her temper!'

2. Cursed, hurtful / pain, doubtful, admiring, astonishing, and inviting

interjections:

/ pisik palondeng! = danunene:m! = dannunena:m! / 'serves you right!'

/ sulano! oko nisaleabi u golosa?! / 'May thunder hits you!'

/ adu: Tumpu! / 'Ouh, my god!'

/ adede:! matangku nopulingon! / 'ugh, my eyes sore!'

I o Tumpu!, mogisala? aku? / ' Oh god!, forgive me!'

/ adu:! nan:ta? oko! / 'Ugh!, it is pity on you!'

/ a:! aiya mian ma?ima?! / Ah!, how delicious it is!'

/ be: indo:! , pit bu?o aiya! / 'Oh! new bike!'

/ e:! dumai oko! / 'Hi! Come here!'

layo:!, da:t li:tno bukubukuan! /'Come on! Pull the rope strongly!'

\subsection{Particles}

Particles are common function words that are not always put with the word that precedes them in which they seem to look like enclitic morphemes. The particles of Andio language found were as follow: / - mo / 'please!' This enclitic morpheme forms command sentences and puts an emphasis on a statement. The following were the examples:

1. I sule? / 'go home' - / sule?mo mo?ona! / 'Please go home first!'

2. I ma:pa / 'go' - / ma:pamo da?ida:m! / 'Please go alone!'

3. / ka:n / 'eat' - / kan:mo bibi:no! / 'Please eat all!'

4. / oko / 'you' - / okomo tongko? mongkeke bubung / 'Please you alone dig the well' I malo? / 'ayah' - / malo?mo mian ma:pa kaurong tasi / 'Please just father goes here.'

5. I inango / 's/he' / inangomo powale? mian larapada:i /'S/he's the well known cheater.'

The descriptions of the findings are directed to answer the research question: "How do function words of Andio language appear in a sentence, a clause, and a phrase?" In line with the research problem, the following are the answers of the question above.

Based on the findings, it has been found that Andio language has several function words that have certain patterns in a phrase, a clause, and a sentence presented respectively below.

\subsection{Function Words Inspected from Syntactic Characteristics}

Syntactically, the features of function word of Andio language could be identified from their patterns in a phrase, a clause or a sentence. The following are the transcript experts of function words in a phrase, a clause or a sentence.

\subsection{Positions of Function Words in a Phrase}

Before presenting the experts of Andio function words, the researcher needs to reveal what the phrase is. Phrase is a small unit of syntax together its function as a connector. So phrase can consist of one or more words (Samsuri, 1981). Based on this definition, the Andio function words are viewed from two type patterns such as (1) endocentric phrase, and (2) exocentric phrase. Let's consider the following examples. 


\subsection{Function Words in an Endocentric Phrase}

A pattern is called endocentric when its distribution patterns are similar with the second, the third, or one of its immediate constituents (Samsuri 1981). The attributively endocentric pattern is clued by one of immediate constituents acting as a head $(\mathrm{H})$ and another one as a modifier $(\mathrm{M})$. Referring to these statements, it has been found that Andio language has several function words having (a) the attributively endocentric patterns, and (b) the coordinately endocentric patterns. Here the examples are below.

\subsection{1 (a) The Attributively Endocentric Patterns}

\subsubsection{Indefinite Numeral (Determiners) + Noun (Modifier + Head)}

/ (M) biai + $(\mathrm{H})$ sawe? / 'many guests'
I (M) teineng $+(\mathrm{H})$ mian / 'few people'
I (M) topopia + $(\mathrm{H})$ pudung / 'several stalks'
I (M) sa?angu + (H) bonua / 'a house'
I (M) bibi?no + $(\mathrm{H})$ inabu / 'all gardens'

\subsubsection{Noun + Demonstrative Pronounce (Determiners) - Head + Modifier}

I $(\mathrm{H})$ pasanga? + (M) aiya / 'shirt + this' - This shirt.

I $(\mathrm{H})$ bonua + aido / 'house + that' - That house.

I (H) kaka:n + (M) mama:Ion / 'rice + this morning' - This morning rice.

I $(\mathrm{H})$ kulabu? + (M) karomdom / 'porrige + last night' - Last night porridge.

I (H) du?ong + (M) kamalom / 'fish + yesterday' - Yesterday fish.

\subsubsection{Adverbs of Manners (Qualifiers) + Adjectives - Modifier (M) + Head (H)}

I (M) pakaya? + (H) masakit / 'always sick'

I (M) ba:lamasi: + $(\mathrm{H})$ mari:ngi? / 'rarely dirty'

I (M) lai?no + momaso? / 'still angry'

\subsubsection{Verbs + Adverbs of Times (Qualifiers) - Head + Modifier}

/ $(\mathrm{H})$ minsule? + (M) no?ila / 'go home tomorrow.'

I $(\mathrm{H})$ moturu + $(\mathrm{M})$ kodi? / 'sleep for a moment'

/ (H) ma:pa + (M) mule? / 'go again.'

\subsubsection{Adverbs of Manners (Qualifiers) + Verbs - Modifier + Head}

I (M) kaekae? + (H) mongka:n / 'being eating'

I (M) lai?no + $(\mathrm{H})$ molobu? / 'still take a bath'

I (M) pakaya? + (H) toka / 'always come'

\subsubsection{Adverbs of Manners + Verbs + Adverbs of times - Modifier + Head + Mo.}

I (M) lai?no + (H) nitulungi + (M) no?ila / 'still being helped tomorrow'

I $(\mathrm{M})$ ba:lamasi: $+(\mathrm{H})$ toka $+(\mathrm{M})$ ka? ipuan / 'rarely came last year.]

I (M) arani + $(\mathrm{H})$ nomate + $(\mathrm{M})$ ka:malom / 'almost died yesterday.'

\subsection{2 (b) Coordinately Endocentric Patterns}


The features of this pattern are indicated by involving conjunctions that joining two or more main constituents having the same status and acting as heads (content words). The conjunctions acting as function words are: / tiba / 'and,'

I kabai / 'or,' / ko?aitu / 'but.' These coordinate conjunctions are used to join Noun phrases, Verb phrases, and Adjective phrases. Here were their examples presented below:

3.15.2.1 The function word / tiba / 'and' in the NP is pinched by Nouns

\section{Noun + Conjunction + Noun \\ / so:pan + tiba + lawang / 'door and window.' \\ / asa? + tiba + boloti / 'cat and mouse.' \\ I marisa + tiba + timuson / 'red pepper and salt.'}

3.15.2.2 The function word / tiba / 'and' in the VP is pinched by Verbs

\section{Verb + Conjunction + Verb}

I mombasa + tiba + montulis / 'to read and to write.'

I molobu? + tiba + mombusoi / 'to take a bath and to wash.'

I mongundan + tiba + monsinanga / 'to cook and to fry.'

I montapa + tiba + montanali / 'to burn and to roast.'

\subsubsection{The function word / tiba / 'and' in the Adj.P is pinched by Adjectives}

\section{Adjective + Conjunction + Adjective}

/ pande + tiba + makeker / 'clever and diligent.'

/ bobo? + tiba + moluluk / 'stupid and lazy.'

/ gentung + tiba + malayo? / 'thin and high.'

\subsubsection{The function word / kabai / 'or' in the NP is pinched by Nouns}

\section{Noun + Conjunction + Noun}

/ utan + kabai + dabudabu / 'vegetable or chilly.'

/ isi: + kabai + du? ong / 'meat or fish'

/ piso? + kabai + pasul / 'knife or mattock.'

\subsubsection{The function word / kabai / 'or' in the VP is pinched by Verbs}

\section{Verb + Conjunction + Verb}

I ma:pa + kabai + dumodongo / 'to go or to stay.'

I tumando + kabai + molomi / 'to cry or to laugh.'

/ minso?obue + kabai + mintede / 'to urinate or to shit.'

I balimang + kabai + moturu / 'to work or to sleep.'

\subsubsection{The function word / kabai / 'or' in the AdjP is pinched by Adjectives}

\section{Adjective + kabai + Adjective}

I gora + kabai + moto? / 'noise or lonely.'

I moluluk + kabai + makeker / 'lazy or diligent.'

/ lotok + kabai + marani? / 'cool or hot'

I mari:ngi? + kabai + moloe? 'dirty or clean.'

/ molongo? + kabai + magentung / 'fat or thin.' 


\subsection{The Positions of Function Words in an Exocentric Phrase Type}

A pattern is called exocentric when its combinations have different form classes from its immediate constituents. Since these class combinations are not similar to one of its constituents, the exocentric pattern always does not have a head. The directly particle exocentric patterns have been found in Andio language by using prepositions. The prepositions act as function words combining with nouns. Here were the examples presented below.

\subsubsection{The function words / utadumai /, /urongduma /from' precede nouns}

\subsubsection{Preposition + Noun}

I utadumai + babono / 'from hill/mountain.'- used from a high place to a low place

I urongdumai + kauno /'from river' - used from a low place to a high place.

/ udodumai + inabu / 'from garden' - is used for a flat place.'

\subsubsection{Preposition + Preposition + Article + Noun}

I udodumai + sambira? $+u+$ bonua / 'from outside of the house.'

/ udodumai + bungkuk $+u+$ bonua / 'from behind of the house.'

\subsubsection{The function word / idodumai rarom / 'from inside' Preposition + Preposition + Article + Noun}

I idodumai + rarom + u + inabu / 'from inside the garden.'

/ idodumai + rarom + u + kauno / 'from inside the river.'

/ idodumai + rarom + u + ronok / 'from inside the bush.'

/ idodumai + rarom + u + bonua / 'from inside the house.'

I idodumai + rarom $+u+$ bolo? / 'from inside the hole.'

3.16.3 The function words / kauta /, / kaurong / 'to,' / tiba / 'with,' / bo?ai / 'for,' / singko / 'like,' / ara?arani / 'around.'

\section{Preposition + Noun}
I kauta + baboon / 'to the hill'
/ kaurong + tasi / 'to the sea'
/ tiba + malo?/tuma / 'with father'
/ bo?ai + ina / 'for mother'
/ singko + kodo? / 'looks like monkey'
/ ara?arani + kura / 'around forest'

3.16.4 The function words / pa:tu / 'under,' / babo: / 'on,' / soripi / 'beside,' / sambira / 'out,' / rarom / 'inside,' / bungkuk / 'behind,' / ola? / 'between,' These prepositions are followed by an article / u / 'the' + nouns.

\section{Preposition + Article + Preposition}

/ babo: + u + atop / 'on the roof.'

/ soripi + $u+$ alewat / 'beside the fence.'

/ sambira + $u+$ bonua / 'outside the house.'

I rarom $+u+$ poturuan / 'inside the room.'

/ ola? + u + alewat/alebat / 'between the fences.'

/ ara?arani $+u+$ kura? / 'around the forest.'

\subsection{The positions of Function Words in a Clause}

The function words of Andio language are described in two types of clause: Independent Clause and Dependent Clause 


\subsubsection{Independent Clause}

Independent clause can stand alone as a complete sentence, and it can appear either as the basic sentence or a derivative sentence. It can appear in a compound sentence by involving conjunctions as the function words: / mokonomo / 'so,' / tiba / 'and,' / ko:a?itu / 'but,' / lalu / 'then,' / mausa?itu / 'however.' Here are their examples below.

1. / topopia ara?itu mongka:n loka? tiba mian sangga?at ma:pa molobu? I

'Several of them have lunch and the others go to take a bath.'

2. / ara?itu mosele ka?i ko:a?itu aku? mosele ko?anan / 'They turn to the left but I turn to the right.'

3. / lean batu aido nibira lalu nitibarakon kaurong tasi / 'The stone dish is broken then it is thrown to the sea.'

4. I oko lapasmo nongka:n biai utan tiba kaka:n mausa?itu oko lai?no megentung./

'You have eaten much vegetable and rice, however you are still thin.'

\subsubsection{Dependent Clause}

The dependent clause cannot stand alone as a complete sentence but it can become a minor sentence. The dependent of the clause can be seen when the clause appears in a compound sentence involving subordinate conjunctions as the function words, for examples: / ka? / 'because,' / maumule? / 'even though,' / sampe / 'when,' / kalu / 'if.' Here their examples are below.

1. / inango ba:la mongka:n ka? inango mapane / 'S/he does not eat because s/he is ill.'

/ inango tumangis ka? pitno aido nibuntolakon kaurong I soroso /

'S/he cries because his/her bike is pushed to the ditch.'

2. / tina momeso pae maumule? inango masakit kompong /

'Mother pounds rice even though she is stomachache'

/ tuma mokoala mimpololo? mongkalia? maumule? tengker kai?no pengko /

'Father can run fast even though his left foot is lame.'

/ biai mian notoka mongka:n i bonuanto maumule? Bonuanto maringi /

'Many people came to eat at our house even though our house was dirty.'

3. / oko da: ma:pa sampe lapasmo mongka:n / 'You may go when you have eaten.'

/ i kele? dumongkok sampe inango mongundan i polu? I

'Grandmother sits when he cooks in the kitchen.'

4. / aku? balimang kalu nitulungi i tai? I 'I work if being helped by grandfather.'

I tai?to katoka I bonuanto kalu komiu ba:la maso? I

'Our grandfather will come to our house if you are not angry.'

\subsection{The Positions of Function Words in a Sentence}

The function words of Andio language have been found appearing in three types of sentence: (1) compound sentence, (2) complex sentence, and (3) compound-complex sentence. Here were their examples presented below.

\subsubsection{Compound Sentences}

The complex sentence of Andio language has been found having two or more full predications in the form of independent clauses. The function words in the compound sentence have coordinately endocentric patterns, such as: Clause + Conjunction + Clause. The function words as conjunctions usually used in Andio language are / kabai / 'or,' / tiba / 'and,' I ko:a?itu / 'but.' Here were their examples are revealed below.

1. / oko da: dongo kabai ma:pa tiba inango / 'You may stay or go with her/him.'

/ ara?itu toali dumongkok mongka:n kabai mokoro mongka:n / 'They may sit eating or stand eating.'

2. / topesanno magentung ko:a?itu inango maroson baliman / 'Your cousin is thin but s/he is strong to work.'

I kele? Lapas rongang ko:a?itu inango bukuan mongka:n dole? I

'Grandmother has been toothless but she is strong to eat corns.'

I malo? tararu mangkeng ko:a?itu inango ba:la mogiso: / 'Father is very tired but he does not complain.'

3. / aku? masakit bese? tiba oko masakit kompong / 'I am toothache and you are stomachache.' 
I kele? Mongundan boas tiba tai? momboit pisop? / 'Grandmother cooks rice and grandfather grinds a knife.' I ara?itu morudak pae tiba aku? monsu?an pae / 'They plant non-irrigated rice and I plant irrigated rice.'

\subsubsection{Complex Sentences}

The complex sentence is a sentence having two or more full predications. One of these is an independent clause (or, main clause) that is similar to the form of the simple sentence, and one or more of these are dependent clauses (or subordinate clauses). The complex sentence of Andio language has the objectively exocentric types. The complex sentence is called the objectively exocentric construction when the object of complex sentence does not have the same function in a complex sentence as any one of its immediate constituents. The function words as conjunctions used in the complex sentence are found as follows: / aitudoka / 'then,' / lapas aido / 'after that,' / ka?aitudo / 'so that,' / lapas / 'after,' / mian / 'which, that, who,' / ba:lape:no / 'before,' / ka? = gau? / 'because,' / wakitu: / 'when, for example.' The following are the transcript excerpts of the above function words as conjunctions.

1. / malo? = tuma mongka:n kaka:n aitudoka inango monginum uwe / 'Father eats rice then he drinks water.'

I tina montambu? uwe aitudoka inango molobu? / 'Mother draws out water then she takes a bath.,

2. / aku? mombaka uwe lapas aido aku? nombaso?i pasanga?ku / 'I carry water after that I wash my cloths.'

/ ara?itu nombaluk mosoni lapas aido ara?itu ma:pa i bonuangku /

'They sold gold after that they went to my house.'

I topesan miu noroyot lapas aido inango nongipi / 'Your cousin slept after that s/he dreamt.'

3. / oko lapasmo nino: balimang ka?aitudo oko da: ma:pa / 'You have worked hard, so you may go.'

/ daokto lapasmo nipitadui kaudo ka?aitudo oko tioda: monggaga?no /

'Your sister/brother in law has been ordered to go there, therefore, you have to call her/him.'

/ aku? nigaga?i balimang ka?aitudo aku? notoka montulungi komiu /

'I was called to work, so I came to help you.'

4. / aku? nongoli pasanga? bu?o lapas kubaluk paengku / 'I bought a new shirt after I sold my rice.'

/ perapa nonggaul poturuan lapas inango nemenek rinding /

'A robber pried the living room after he climbed the wall.'

I babo: nongka:n kaka:n lapas inango nomboso?i limano / 'Uncle ate rice after he washed his hands.'

5. I tai? mongkira monsu?an pae maumule? inango ba:la mongka:n kaka:n /

'Grandfather likes to plant rice although he does not eat rice.'

/ sila:bo? mami nombokoki aku? maumule? aku? ba:la nomangon oi?no /

'My mother in law beat me even though I did not steal her money.'

/ ara?itu ba:la nontidu?i bisara Andio maumule? ara?itu lapasmo nibeai doi? /

'They did not teach Andio even though they had been given money.l

6. I asa? mian norakop bokoti, nongka:n du?ongku / 'The cat catching (which caught) the mouse, ate my fish.'

/ bonia mian norangkubi manu?, nontongol boroko u manu? Aido /

'The hawk swooping down and seizing (which swooped down and seized) the baby chick, bit the chick's neck.'

7. I aku? mongoli loka sampe kutou:no:I doi? / 'I buy a banana if I have money.'

I monian bobine tumangis sampe oko ma:pa morakop ulo? / 'Mother in law cries if you go to catch a snake.'

/ monian ma?ane bo: monta: pu: sampe ara?itu montulungi inango /

8. I tina bo: mombei oko doi? kalu oko montulungi inango / 'Mother will give you money if you help her.'

I babo: toali mokoro bonua kalu inango montou:i tano / 'Uncle may build a house if he has land.'

9. / daokto nontulungi bengkele?no ba:lape:no inango ma:pa balimang /

'You/Our brother in law helped his wife before he went to work.'

/ sila:bo?no nonsea isi: ba:lape:no inango nombaso?i lean /

'Her/his mother in law sliced meat before s/he washed a dish.'

I kele? nomboit piso? ba:lape:no kugaga?ino mongka:n / 'Grandmother ground knife before I called her to eat.'

10. / aku? nonsikotno gau? inango nonduruk doi?ku / 'I tied him/her up because s/he took my money.'

/ tuma nomomol asa? ka? i asa? nongka:n kaka:nno / 'Father beat the cat because the cat ate his rice.'

/ tina nobaluk pasanga?no ka? inango nongkira nongoli boas /

'Mother sold her skirt because she wanted to buy rice.' 
11. / langkai?ku kaekae mongka:n paran wakitu: komiu mongga?i inango /'My husband is eating pineapple when you call him.' / bengkele?ku kaekae nonginu? uwe wakitu: tai? nomboboki anakku /'My wife was drinking water when grandfather beat my kid.'

I ara?itu nota:p kauno wakitu: kubuani du?ong i kauno / 'They crossed the river when I netted fish in the river.'

\subsubsection{Compound Complex Sentences}

Compound complex sentences contain two or more independent clauses and one or more dependent clauses. Such sentences in Andio language use function words as conjunctions. Here were their examples found in Andio language using / ... tiba ... mian / ' ... and ... which, that, who,'l ... mian ... mian / '... which, that, who ... which, that, who ...'

/ aku? nomakanasai tiba nomparesa inabu mian kuoli ka:malom /

'I investigated and observed the garden which/that I bought yesterday.'

/ inango nonsinanga tiba nongundan du?ong mian niteleng u tuma /

'S/he fried and cooked fish which/that was fished by father'

/ tonngol nongkokop tiba nomboboki posoriapanno mian nomangan piso?no /

'The village chief caught and beat his neighbor who stole his knife.'

I tina nomapui du?ong mian ubalukakon posoriapan mian toka utadumai taugi /

'Mother burned fish which was sold by neighbor who came from Taugi.'

/ tuma nomo:i asa? mian nongka:n du?ong mian tuma nongoli i pasar /

'Father beat the dog which ate the fish that he bought in the market.'

I naung nongoli pit mian nipakaima?i u topesanku mian tumompil I bonuangku I

'Aunt bought bicycle which was repaired by my cousin who slept in my house.'

\section{Conclusion and Suggestions}

\subsection{Conclusion}

Based on the findings of descriptive data of the function words, Andio language has been found having twelve types of function words. Those function words are as follows:

(1) Noun determiner - is a word usually appearing before a noun. It describes the amount of a noun, (2) Qualifier is an adjective word modifying an adjective, an adverb, a verb, and a noun, (3) Preposition - is a word used to form a prepositional phrase. It usually appears before a noun, and an adjective functioning as an adverb, (4) Coordinate Conjunction - combines structural units that are identical grammatically. The conjunction appears before the last unit and is grammatically independent of this unit, (5) Interrogator - is a word used to ask information, (6) Subordinating conjunction - introduces a clause that depends on a main, or independent clause. The subordinate conjunction is grammatically part of the clause it introduces; it is never separated from its clause by a comma (Frank, 1972), (7) Transitional Signals / Sentence Linkers - are exerted to combine sentences into continuous text. They provide logical relationships that hold between sentences or stretches of text, marked by the use of logical connectors (Mackay et al., 1979), (8) Modal Auxiliaries - are words used to ask something that uncertainly happens. The modal auxiliaries of Andio language always appear before a predicator, (9) Interjection - is a word used to present humans' feelings, (10) Aspect words - deal with certain verbs, often with accompanying adverbial expressions, may indicate whether an event is to be considered as a single point on a time continuum, a repetition of points, or a single duration with a beginning, a middle and an end. It is the aspect of duration that a verb most readily present through the progressive forms of the tenses (Frank, 1972), (11) Particle - is a function word that is not always occurring before a word that precedes it in which it seems to look like an enclitic morpheme. This enclitic morpheme of Andio language means 'please!', and (12) Relative pronouns - are concerned with noun antecedents which immediately precede them. They introduce adjective clauses in which they serve as subjects or objects (Frank, 1972).

\subsection{Suggestions}

Andio language is one of vernaculars in Central Sulawesi that will undergo extinction. Its indigenous speakers are about 
1.500 people living at two villages - Tangeban and Taugi villages. Its new generation speakers almost forget many vocabularies, and moreover, many vocabularies coming from other vernaculars around this village become loan words. Only old men still know well the original vocabularies of this language. Its new generation speakers do not used it in their daily life and in their society. Its vocabularies in terms of function words in particular, and its content words in general might be extinction. Therefore, only the loan words will be dominant in this language because its original vocabularies have lost from the new generation speakers' brains.

To keep the preservation of this vernacular from extinction, it is suggested that this language must be inventoried, and noted. It is also suggested that any researchers who are interested in a scientific research, should carry out another investigation to probe other aspects of Andio language in general, and function words in particular.

\section{References}

Aryl, D., Jacobs, L.C. and Razavieh, A., 1979. Introduction to Research in Education. New York: Holt, Rinehart and Winsto. Berg. B.L., 1989. Qualitative Research Methods for the School. London: Allyn and Bacon, Inc.

Bogdan, R.C., 1998. Qualitative Research Introduction: An Introduction to Theory and Methods. Boston: Allyn and Bacon, Inc. Frank, M., 1972. Modern English: a practical reference guide. New Jersey: Englewood Cliffs.

Keraf, G. 1969. Tata Bahasa Indonesia. Jakarta: Penerbit Nusa Indah.

Kridalaksana, H. 1982. Kamus Linguistik. Jakarta: PT. Gramedia.

Miles, B.M., \& Huberman, A.M., 1989. Qualitative Data Analysis. London: Beverly Hills, Saga Publications, Inc.

Patton, M.G., 1980. Qualitative Evaluation Methods. California: Beverly Hills, Saga Publications, Inc.

Parera, J.D. 1976. Pengantar Linguistik Umum. Plores: Penerbit Nusa Indah.

Quirk, R., \& Greenbaum, S., 1973. A University Grammar of English. New York: Longman.

Robins, R. H. 1980. General Linguistics, An Introductory Survey. New York: Longmans Ltd.

Samsuri, 1981. Analisa Bahasa, Jakarta: Penerbit Erlangga.

Stryker, S. 1969. Applied Lingustics, Principles and Techniques. English Teaching Forum, Vol. II, No. 5.

Taylor, S.J. \& Bogdan, R. 1984. Introduction to Qualitative Research: The Research for Meaning. New York: John Wiley.

Verhaar, J.W.W. 1982. Pengantar Linguistik, Jilid I. Jogyakarta: Gaja Mada University Press. 
